\title{
ANALISIS PENERAPAN SUSTAINABLE DEVELOPMENT GOALS (SDGs) PADA BEBERAPA ANGGOTA INDONESIA GLOBAL COMPACT NETWORK (IGCN)
}

\author{
Theresia
}

\author{
Akuntansi, Universitas Bunda Mulia, DKI Jakarta, theresia.weasley@yahoo.com
}

\begin{abstract}
ABSTRAK:
Penelitian ini bertujuan untuk melihat bagaimana pelaksanaan CSR berdasarkan kriteria SDGs untuk perusahaan yang tergabung dalam Indonesia Global Compact Network (IGCN) di Indonesia.Penelitian ini penting karena pengukapanCSR perusahaan merupakan informasi penting bagi pemangku kepentingan saat ini di dalam pengambilan keputusan.Perusahaan tidak lagi hanya dinilai dari kinerja keuangan, tetapi juga kinerja sosial dan lingkungan.Penelitian ini merupakan penelitian kualitatif deskriptif dengan sumber data sekunder dari laporan keberlanjutan yang dipublikasikan perusahaan selama 2 tahun berturut untuk melihat kontinuitas pengungkapan.Subjek penelitian adalah 7 perusahaan sebagai representatif anggota IGCN.Teknik pengumpulan data dengan dokumentasi dari website perusahaan dan analisis dengan content analysis.Dari hasil penelitian, dapat disimpulkanbahwa pengungkapan CSR untuk 7 perusahaan yang menjadi subjek penelitian sudaj memenuhi kriteria SDGs terutama pada aspek sosial.
\end{abstract}

Berdasarkan hasil penelitian dan pembahasan, maka dapat ditarik simpulan sebagai berikut: (1). Pengungkapan CSR perusahaan apabila ditinjau dari 17 kriteria SDGs tampak masih perlu untuk dikembangkan. Hasil analisis menunjukan terdapat 6 kriteria yang diungkapkan dari 17 kriteria oleh 7 perusahaan yang merupakan subjek penelitian. (2). Tampak dari tabel 1, pengungkapan perusahaan tahun 2015 dan 2016 konsisten artinya informasi yang diungkap 2015, diungkapkan kembali dengan perkembanagn di tahun 2016. Hal ini tampak dari kriteria yang diungkapkan di 2015, oleh perusahaan tersebut diungkapkan kembali di 2016. (3). Pengungkapan yang dominan lebih ke arah sosial daripada lingkungan seperti: kesehatan dan kesejahteraan,pendidikan, air bersih dan sanitasi, konsumen dan kemitraan. Kriteria pada arah lingkungan adalah pemakaian energi.

Kata Kunci: SDGs, IGCN, CSR, content analysis

\section{ABSTRACT:}

This research aims to look at how implementation of CSR based on the criteria of SDGs for companies incorporated in Indonesia Global Compact Network (IGCN) in Indonesia. This research is important because pengukapan corporate CSR is important information for current stakeholders in the decision making. The company is no longer just votes from financial performance, but also the social and environmental performance. This study is a qualitative descriptive study with a secondary data source from a report published sustainability company for 2 years consecutive to see continuity disclosure. The subject was the company as representative members IGCN. Data collection techniques with documentation from company websites and analysis with content analysis. From the 


\section{National Conference of Creative Industry: \\ Sustainable Tourism Industry for Economic Development}

Universitas Bunda Mulia, Jakarta, 5-6 September 2018

ISSN No: 2622-7436

results of the research, it can be concluded that disclosure of CSR to the company being the subject of the 7 research meets the criteria sudaj SDGs especially on social aspects.

Based on the results of research and discussion, then it could be drawn in summary as follows: (1) disclosure of corporate CSR in terms of 17 criteria SDGs looks still need to be developed. The results of the analysis showed there are 6 criteria disclosed by criteria 7 of the 17 companies that is the subject of research. (2) it appears from table 1, the company's disclosure of the year 2015 and 2016 consistent means that the information revealed by 2015, expressed again with perkembanagn in the year 2016. This looks from the criteria expressed in 2015, the company disclosed back in 2016. (3) the dominant Disclosure more toward social rather than the environment such as: health and wellbeing, education, clean water and sanitation, consumer and partnership. Criteria on the direction of the environment is energy consumption.

Keywords: SDGs, IGCN, CSR, content analysis

\section{PENDAHULUAN}

Kesadaran masyarakat yang semakin meningkat akan pentingnya peran perusahaan dalam lingkungan sosial menjadikan masyarakat membutuhkan informasi mengenai sejauhmana perusahaan telah melaksanakan aktivitas sosialnya (Budiman, 2015). Secara umum Corporate Social Responsibility(CSR) merupakan peningkatan kualitas kehidupan dengan adanya kemampuan manusia sebagai individu anggota masyarakat untuk menanggapi keadaan sosial yang ada dan dapat dinikmati, memanfaatkan, serta memelihara lingkungan hidup. Atau dengan kata lain merupakan cara perusahaan mengatur proses usaha untuk memproduksi dampak positif pada komunitas. Selain itu CSR meliputi tanggung jawab di bidang ekonomi dalam upaya menciptakan standar hidup lebih baik dengan tetap memelihara profitabilitas perusahaan (Ermawati, 2014 dalam Antule et al. 2016). CSR menurut Bank Dunia adalah komitmen perusahaan untuk berperilaku etis dan memberikan kontribusi bagi pembangunan berkelanjutan melalui kerjasama dengan segenap pemangku kepentingan yang terkait untuk memperbaiki hidup mereka dengan cara-cara yang baik bagi kepentingan bisnis, agenda pembangunan berkelanjutan, dan masyarakat pada umumnya (Kiroyan, 2009 dalam Aryawan et al. 2017).

Pada September 2015, PBB melakukan resolusi yang dinamakan Sustainable Development Goals (SDGs) sebagai target pembangunan bersama sampai tahun 2030.SDGs merupakan agenda internasional yang menjadi kelanjutan dari Tujuan Pembangunan Milenium atau Millennium Development Goals (MDGs).SDGs disusun oleh Perserikatan Bangsa-Bangsa (PBB) dengan melibatkan 194 negara, civil society, dan berbagai pelaku ekonomi dari seluruh penjuru dunia.Agenda ini dibuat untuk menjawab tuntutan kepemimpinan dunia dalam mengatasi kemiskinan, kesenjangan, dan perubahan iklim dalam bentuk aksi nyata. SDGs ditetapkan pada 25 September 2015 dan terdiri dari 17 (tujuh belas) tujuan global dengan 169 (seratus enam puluh sembilan) target yang akan dijadikan tuntunan kebijakan dan pendanaan untuk 15 tahun ke depan dan diharapkan dapat tercapai pada tahun 2030. Tujuan dan target tersebut meliputi 3 (tiga) dimensi pembangunan berkelanjutan, yaitu lingkungan, sosial, dan ekonomi. 


\section{National Conference of Creative Industry: \\ Sustainable Tourism Industry for Economic Development}

Universitas Bunda Mulia, Jakarta, 5-6 September 2018

ISSN No: 2622-7436

Dengan adanya kesadaran mengenai pentingnya aspek tanggung jawab sosial, maka terbentuklah organisasi Indonesia Global Compact Network (IGCN) pada tahun 2006, untuk memberikan dukungan kepada perusahaan-perusahaan yang tergabung dalam organisasi ini. Indonesia Global Compact Network (IGCN) memiliki misi ntuk mempromosikan, memfasilitasi dan menerapkan Prinsip UN Global Compact(UNGC) di Indonesia serta untuk mempercepat transformasi negara menuju pencapaian hak asasi manusia, tenaga kerja kompetitif, lingkungan yang berkelanjutan, dan praktik bisnis yang etis.

Penelitian ini penting untuk melihat sejauh mana kriteria SDGs sudah dipenuhi oleh perusahaan di Indonesia yang merupakan bagian IGCN serta pada kriteria mana pengungkapan sudah banyak dilakukan ataupun yang masih terbatas pengungkapannya.Pengungkapan yang terbatas mengindikasikan pelaksanaannya masih belum dimaksimalkan.Diharapkan dari penelitian ini memberikan kontribusi bagi perusahaan untukmeningkatkan pengungkapan CSR yang memenuhi kriteria SDGs yang sejalan dengan prinsip UNGC.Dalam praktik akademis, dapat menjadi referensi pengungkapan CSR berdasarkan kriteria SDGs di Indonesia untuk dijadikan indikator variabel CSR penelitian selanjutnya.Sebagai tambahan, penelitian ini memberikan informasi konsistensi pengungkapan perusahaan untuk setiap kriteria selama 2 tahun analisis.

\section{TINJAUAN PUSTAKA}

Teori Legitimasi merupakan sistem pengelolaan perusahaan yang berorientasi pada keberpihakan terhadap masyarakat (society), pemerintah individu dan kelompok masyarakat (Hadi, 2014).Perbedaan antara nilai perusahaan dengan nilai masyarakat sering diartikan sebagai "legitimacy gap" yang akan mempengaruhi kemampuan perusahaan dalam melanjutkan kegiatan usahanya (Lindawati dan Puspita, 2015). Apabila operasi perusahaan (corporate activities) sesuai dengan pengharapan masyarakat (society's expectations) maka akan terjadi kesesuaian termasuk kesesuaian pada nilai sosial dan norma dan sebaliknya. Akan timbul 3 (tiga) hal yang menyebabkan legitimacy gap terjadi yaitu, pertama adalah ada perubahan dalam kinerja perusahaan, tetapi harapan masyarakat terhadap kinerja perusahaan tidak berubah.Perusahaan yang sebelumnya melaksanakan tanggung jawab sosialnya secara rutin kemudian menghentikan pelaksanaan program tersebut dengan berbagai alasan.

Masalah legitimasi kemudian muncul karena terjadi perubahan kinerja perusahaan namun di sisi lain masyarakat telah bergantung pada program rutin tersebut dan tidak ingin dihentikan. Kedua, adalah kinerja perusahaan tidak berubah namun harapan masyarakat terhadap kinerja perusahaan sudah berubah.Masyarakat mengharapkan perusahaan untuk memberikan kepedulian lebih dari sekedar sumbangan kemanusiaan seperti jaminan hidup dengan membuka kesempatan bagi masyarakat lokal untuk bekerja di perusahaan tersebut. Sedangkan perusahaan menganggap bahwa dengan membuka peluang kerja bagi masyarakat sekitar tidak akan memberikan efek positif bagi perusahaan karena adanya keterbatasan pendidikan sehingga hal tersebut tidak dilakukan. 


\section{National Conference of Creative Industry: \\ Sustainable Tourism Industry for Economic Development}

Universitas Bunda Mulia, Jakarta, 5-6 September 2018

ISSN No: 2622-7436

Kemudian ketiga adalah kinerja perusahaan dan harapan masyarakat berubah ke arah yang berbeda atau ke arah yang sama dalam waktu yang berbeda. Perusahaan menggunakan masyarakat sekitar sebagai tenaga kerja di perusahaan tersebut karena dianggap lebih murah dan saat itu angka pengangguran di lingkungan tersebut berkurang.Namun kemudian perusahaan melakukan pemutusan hubungan kerja dan yang terkena dampak adalah masyarakat local yang bekerja di perusahaan tersebut.Perusahaan mengganti tenaga kerja manusia menggunakan mesin karena dianggap lebih menguntungkan bagi perusahaan dan dapat mengurangi beban perusahaan.Masyarakat menerima keputusan tersebut dan berharap perusahaan tetap membantu kehidupan mereka yang selama ini ditopang dari upah yang diberikan perusahaan dengan memberikan bantuan pembiayaan usaha kecil menengah bagi masyarakat.Masalah legitimasi muncul ketika perusahaan tidakmemenuhi harapan mereka tersebut.Untuk memperkecil adanya legitimacy gap maka perlu dilakukannya lebih banyak pertemuan antar stakeholder maupun antara stakeholder dengan perusahaan.Kegiatan CSR yang dilakukan perusahaan juga harus lebih difokuskan pada kebutuhan stakeholder, berdasarkan evaluasi dan analisis kebutuhan.Kemudian, pengungkapan dalam laporan tahunan perusahaan harus menggambarkan informasi aktual tentang kegiatan sosial yang dilakukan perusahaan untuk ketertarikan pembaca.

Teori stakeholder menjelaskan bahwa tiap pemangku kepentingan turut menentukan kinerja perusahaan, termasuk kinerja sosialnya.Institusi dianggap sebagai pihak yang paling mampu dalam mengawasi dan mengelola investasinya, baik dari segi pengetahuan, sistem informasi, maupun sumber daya yang dimiliki. Kepemilikan institusional yang tinggi akan menimbulkan usaha pengawasan yang lebih besar oleh pihak investor sehingga dapat menghalangi perilaku opportunistic manajer (Aditya dan Suhardianto, 2016). Dengan demikian, dapat disimpulkan bahwa teori stakeholder merupakan suatu teori yang mengatakan bahwa keberlangsungan suatu perusahaan tidak terlepas dari adanya peranan stakeholder baik dari internal maupun eksternal dengan berbagai latar belakang kepentingan yang berbeda dari setiap stakeholder yang ada. CSR dapat menjadi strategi perusahaan untuk memenuhi kepentingan dari para stakeholder akan informasi non keuangan perusahaan terkait dampak sosial dan lingkungan yang timbul dari adanya aktivitas perusahaan. Semakin baik pengungkapan CSR oleh perusahaan akan membuat stakeholder memberikan dukungan penuh kepada perusahaan atas segala aktivitasnya yang bertujuan untuk meningkatkan kinerja dan mencapai laba yang diharapkan (Lindawati dan Puspita, 2015). Tanggung jawab sosial perusahaan diimplementasikan kepada seluruh stakeholder. Tanggung jawab sosial perusahaan yang mengakomodasi kebutuhan dan kepentingan stakeholder timbul sejak adanya kesadaran akan keberlanjutan perusahaan dalam jangka panjang yang ternyata lebih penting daripada peningkatan keuntungan perusahaan semata (George, 2013).

Penelitian terdahulu oleh Sawaka dan Putri (2016). Penelitian ini menggunakan deskriptif kualitatif sebagai teknik analisis data. Penelitian ini bertujuan untuk mengetahui pengungkapan penerapan CSR PT BPD Bali beserta dampaknya. Hasil penelitian ini menunjukkan bahwa penerapan CSR BPD Bali tahun 2014 untuk semua sektor selain energi sudah sesuai dengan standar yang berlaku. Namun untuk sektor energi yang memiliki nilai dibawah standar disebabkan karena secara khusus memang BPD Bali 


\section{National Conference of Creative Industry: \\ Sustainable Tourism Industry for Economic Development}

Universitas Bunda Mulia, Jakarta, 5-6 September 2018

ISSN No: 2622-7436

belum memiliki kebijakan penghematan dan penggunaan energi setiap periodenya. Dasar kuat BPD Bali mengungkapkan penererapan CSR tersebut adalah landasan hukum.

Penelitian oleh Umawan dan Putri (2016). Metode penelitian yang digunakan adalah deskriptif kualitatif. Penelitian ini bertujuan untuk menilai apakah perusahaan sudah menjalankan program CSR dengan baik. Hasil penelitian menunjukkan bahwa penerapan CSR Hotel The Westin Resort pada tahun 2014 untuk semua sektor termasuk penghematan energi dan penggunaan energi setiap periodenya dan limbah sudah memiliki nilai CSRDI lebih dari 50\% ini berarti bahwa pengungkapan penerapan CSR yang dilakukan Hotel sudah dapat dikatakan baik.

Penelitian oleh Wandina, et al (2016). Metode penelitian yang digunakan adalah kualitatif. Penelitian ini bertujuan untuk mengetahui apakah program CSR yang dilaksanakan sudah efektif atau belum. Hasil penelitian menunjukkan Pelaksanaan program CSR PT. Adaro Indonesia didasari karena adanya kesadaran perusahaan akan tanggung jawab terhadap lingkungan dan pengembangan masyarakat. Selanjutnya penerapan program CSR bidang pendidikan seperti program bantuan infrastruktur termasuk bantuan yang efektif Namun ada ditemukan beberapa permasalahan dalam pelaksanaannya seperti ada sekolah yang pernah diberi bantuan, perihal laporan berita acara untuk arsip pihak sekolah ada yang tidak memiliki dan membuat pihak sekolah kesusahan menginput data atau barang yang termasuk hibah.

Penelitian oleh George (2013). Metode penelitian yang digunakan adalah deskriptif kualitatif. Penelitian ini bertujuan untuk mengetahui apakah Program CSR yang dilaksanakan sudah cukup baik. Hasil penelitian mengatakan bahwa plaksanaan CSR mengalami berberapa hambatan terkait dengan kebijakan tanggung jawab sosial perusahaan. Kendala utama dalam implementasi kebijakan tanggung jawab sosial perusahaan di PT. Pembangkit Jawa Bali Unit Pembangkit Gresik adalah belum adanya peraturan pemerintah walaupun sudah ada undang-undang yang memayunginya, yang berdampak pada pelaksanaan kebijakan tanggung jawab social perusahaan belum optimal, sehingga pemerintah diharapkan segera mengeluarkan peraturan pemerintah tentang tanggung jawab sosial perusahaan. Permasalahan lainnya pada PT. Pembangkit Jawa Bali Unit Pembangkit Gresik mengenai kurang mudahnya mendapatkan data penerima CSR berdampak pada penyusunan program CSR walaupun anggaran telah tersedia sehingga koordinasi antara PT PT. PJB UP Gresik dan pemerintah harus lebih ditingkatkan lagi.

Penelitian oleh Asmeri, et al (2017). Penelitian ini menggunakan metode kuantitatif. Penelitian ini bertujuan untuk mengetahui tingkat efektifitas tanggung jawab sosial terhadap profitablitas terkait dengan ROA. Hasil penelitian menunjukkan bahwa kinerja lingkungan memiliki pengaruh positif terhadap ketidakpastian tanggung jawab sosial, sehingga tidak efektifnya pertanggungjawabannya tidak tercermin dalam penangguhan tanggung jawab sosial dan tidak ada efektifitas terhadap profitabilitas yang terkait dengan ROA.

\section{METODE PENELITIAN}




\section{National Conference of Creative Industry: \\ Sustainable Tourism Industry for Economic Development}

Universitas Bunda Mulia, Jakarta, 5-6 September 2018

ISSN No: 2622-7436

Subjek penelitian adalah beberapa perusahaan yang tergabung dalam Indonesia Global Compact Network (IGCN). IGCN adalah Jaringan lokal dari United Nations Global Compact, sebuah jaringan terbesar di dunia untuk gagasan keberlanjutan perusahaan. Sebuah panggilan pada perusahaan untuk menyamakan strategi dan operasi dengan prinsip universal untuk hak asasi manusia, tenaga kerja, lingkungan, dan anti korupsi, dan mengambil tindakan yang dapat memajukan tujuan kemasyarakatan. Indonesia Global Compact Networtk (IGCN) diluncurkan pada tanggal 8 April 2006 di Jakarta selama Konferensi UNESCAP yang dihadiri oleh semua delegasi. Dua puluh dua perusahaan dan organisasi membuat komitmen bersama dan menandatangani janji untuk mendukung, mempromosikan, dan menerapkan Prinsip-prinsip United Nation Global Compact. Visi IGCN adalah menjadi agen perubahan yang terhormat dalam mempercepat transformasi negara menuju pencapaian hak asasi manusia, tenaga kerja kompetitif, lingkungan yang berkelanjutan, dan praktik bisnis yang etis. Misi IGCN adalah untuk mempromosikan, memfasilitasi dan menerapkan Prinsip Global Compact PBB di Indonesia.Ada 51 perusahaan yang tergabung menjadi member IGCN. Dalam penelitian ini, Subjek penelitian terdiri dari 7 perusahaan: PT. XL Axiata. Tbk, PT. Kaltim Prima Coal, Tbk, PT. Unilever Tbk, PT. Adaro, Tbk., PT. Pabrik Kertas Tjiwi Kimia, Tbk, PT. Indah Kiat Pulp \& Paper Tbk.

Penelitian ini menggunakan jenis penelitian kualitatif-deksriptif. Menurut Sugiyono (2014) Pendekatan kualitatif adalah metode yang lebih menekankan pada aspek pemahaman secara mendalam terhadap suatu masalah. Penelitian ini mengutamakan proses penelitian didasarkan pada fenomena ataau bukti-bukti nyata di lapangan. Metode deskriptif bertujuan bertujuan untuk melihat gambaran atau deskripsi secara jelas mengenai keadaan atau gejala tertentu.

Menurut Miles, Huberman dan Saldana (2014) di dalam analisis data kualitatif terdapat tiga alur kegiatan yang terjadi secara bersamaan. Aktivitas dalam analisis data yaitu: Data Condensation, Data Display, dan Conclusion Drawing/Verifications.Kondensasi Data (Data Condensation) merujuk pada proses memilih, menyederhanakan, mengabstrakkan, dan atau mentransformasikan data yang mendekati keseluruhan bagian dari catatan-catatan lapangan secara tertulis, transkip wawancara, dokumen-dokumen, dan materi-materi empiris lainnya.Penyajian Data (Data Display) adalah sebuah pengorganisasian, penyatuan dari infomasi yang memungkinkan penyimpulan dan aksi. Penyajian data membantu dalam memahami apa yang terjadi dan untuk melakukan sesuatu, termasuk analisis yang lebih mendalam atau mengambil aksi berdasarkan pemahaman.Penarikan Kesimpulan (Conclusions Drawing)adalah menarik kesimpulan dan verifikasi. Teknis analisis pada penelitian ini akan mengacu pada proses di atas.

\section{HASIL PENELITIAN DAN PEMBAHASAN}


Tabel 1

Tabel Penyajian Data Berdasarkan Laporan Berkelanjutan Perusahaan

\begin{tabular}{|c|c|c|c|c|c|c|c|c|c|c|c|c|c|c|c|c|c|}
\hline \multirow[t]{2}{*}{ NO } & \multirow[t]{2}{*}{ INDIKATOR } & \multicolumn{2}{|c|}{$\begin{array}{l}\text { PT. XL } \\
\text { Axiata, } \\
\text { Tbk. }\end{array}$} & \multicolumn{2}{|c|}{$\begin{array}{c}\text { PT. Bank } \\
\text { Negara } \\
\text { Indonesia, } \\
\text { Tbk, (BNI) }\end{array}$} & \multicolumn{2}{|c|}{$\begin{array}{c}\text { PT. } \\
\text { Unilever, } \\
\text { Tbk. }\end{array}$} & \multicolumn{2}{|c|}{$\begin{array}{c}\text { PT. Kaltim } \\
\text { Prima Coal } \\
\text { (KPC) }\end{array}$} & \multicolumn{2}{|c|}{$\begin{array}{l}\text { PT. Adaro } \\
\text { Energy, } \\
\text { Tbk. }\end{array}$} & \multicolumn{2}{|c|}{$\begin{array}{c}\text { PT. Pabrik } \\
\text { Kertas } \\
\text { Tjiwi } \\
\text { Kimia, Tbk. }\end{array}$} & \multicolumn{2}{|c|}{$\begin{array}{l}\text { PT. Indah } \\
\text { Kiat Pulp } \\
\text { and Paper, } \\
\text { Tbk. }\end{array}$} & \multirow[t]{2}{*}{$\begin{array}{l}\text { TOT } \\
\text { AL } \\
2015\end{array}$} & \multirow[t]{2}{*}{$\begin{array}{l}\text { TOT } \\
\text { AL } \\
2016\end{array}$} \\
\hline & & 2015 & 2016 & 2015 & 2016 & 2015 & 2016 & 2015 & 2016 & 2015 & 2016 & 2015 & 2016 & 2015 & 2016 & & \\
\hline 1 & Tanpa Kemiskinan & 0 & 0 & 1 & 1 & 0 & 0 & 0 & 0 & 0 & 0 & 0 & 1 & 0 & 1 & 1 & 3 \\
\hline 2 & Tanpa Kelaparan & 0 & 0 & 0 & 0 & 1 & 1 & 0 & 0 & 0 & 0 & 0 & 0 & 0 & 0 & 1 & 1 \\
\hline 3 & $\begin{array}{l}\text { Kesehatan yang Baik } \\
\text { dan Kesejahteraan }\end{array}$ & 1 & 1 & 1 & 1 & 1 & 1 & 1 & 1 & 1 & 1 & 1 & 1 & 1 & 1 & 7 & 7 \\
\hline 4 & Pendidikan Berkualitas & 1 & 1 & 1 & 1 & 1 & 1 & 1 & 1 & 1 & 1 & 1 & 1 & 1 & 1 & 7 & 7 \\
\hline 5 & Kesetaraan Gender & 1 & 1 & 1 & 1 & 0 & 0 & 1 & 1 & 1 & 1 & 0 & 1 & 0 & 1 & 4 & 6 \\
\hline 6 & Air Bersih dan Sanitasi & 0 & 1 & 0 & 1 & 1 & 1 & 1 & 1 & 1 & 1 & 1 & 1 & 1 & 1 & 5 & 7 \\
\hline 7 & $\begin{array}{l}\text { Energi Bersih dan } \\
\text { Terjangkau }\end{array}$ & 1 & 1 & 1 & 1 & 1 & 1 & 1 & 1 & 1 & 1 & 1 & 1 & 1 & 1 & 7 & 7 \\
\hline 8 & $\begin{array}{l}\text { Pertumbuhan Ekonomi } \\
\text { dan Pekerjaan yang } \\
\text { Layak }\end{array}$ & 1 & 1 & 1 & 1 & 1 & 1 & 1 & 1 & 0 & 0 & 0 & 0 & 0 & 0 & 4 & 4 \\
\hline 9 & $\begin{array}{l}\text { Industri, Inovasi dan } \\
\text { Infrastruktur }\end{array}$ & 1 & 1 & 1 & 1 & 0 & 0 & 1 & 1 & 1 & 1 & 1 & 1 & 1 & 1 & 6 & 6 \\
\hline 10 & $\begin{array}{l}\text { Mengurangi } \\
\text { Kesenjangan }\end{array}$ & 1 & 1 & 1 & 1 & 0 & 0 & 1 & 1 & 0 & 0 & 0 & 0 & 0 & 0 & 3 & 3 \\
\hline 11 & $\begin{array}{l}\text { Keberlanjutan Kota dan } \\
\text { Komunitas }\end{array}$ & 1 & 1 & 1 & 1 & 1 & 1 & 1 & 1 & 0 & 0 & 1 & 1 & 1 & 1 & 6 & 6 \\
\hline 12 & $\begin{array}{l}\text { Konsumsi dan Produksi } \\
\text { Bertanggung Jawab }\end{array}$ & 1 & 1 & 1 & 1 & 1 & 1 & 1 & 1 & 1 & 1 & 1 & 1 & 1 & 1 & 7 & 7 \\
\hline 13 & Aksi Terhadap Iklim & 0 & 0 & 1 & 1 & 1 & 1 & 0 & 1 & 0 & 0 & 1 & 1 & 1 & 1 & 4 & 5 \\
\hline 14 & Kehidupan Bawah Laut & 1 & 1 & 1 & 1 & 0 & 0 & 1 & 1 & 0 & 0 & 0 & 1 & 0 & 1 & 3 & 5 \\
\hline 15 & Kehidupan di Darat & 0 & 0 & 1 & 1 & 1 & 1 & 1 & 1 & 1 & 1 & 1 & 1 & 1 & 1 & 6 & 6 \\
\hline 16 & \begin{tabular}{|l|} 
Institusi Peradilan yang \\
Kuat dan Kedamaian \\
\end{tabular} & 1 & 1 & 1 & 1 & 0 & 0 & 0 & 0 & 0 & 0 & 0 & 0 & 0 & 0 & 2 & 2 \\
\hline 17 & $\begin{array}{l}\text { Kemitraan untuk } \\
\text { Mencapai Tujuan }\end{array}$ & 1 & 1 & 1 & 1 & 1 & 1 & 1 & 1 & 1 & 1 & 1 & 0 & 1 & 0 & 7 & 5 \\
\hline
\end{tabular}

Sumber: Laporan Berkelanjutan Perusahaan

Dalam penerapan SDGs pada berberapa perusahaan yang tergabung dalam IGCN, dapat terlihat aspek-aspek yang dominan yang paling banyak menjadi perhatian perusahaan.Aspek yang pertama adalah aspek Kesehatan yang Baik dan Kesejahteraan.Manusia dalam tumbuh kembangnya serta untuk mencapai taraf hidup yang tinggi membutuhkan tingkat kesehatan yang baik.Masyarakat menjadi salah satu stakeholder yang cukup penting bagi perusahaan, terutama yang berada di sekitar wilayah operasional perusahaan.Aspek kesehatan masyarakat perlu untuk disosialisasikan dan perlu ditingkatkan, untuk itulah perusahaan berusaha berkontribusi dalam bidang kesehatan sesuai dengan kemampuannya dan juga kebutuhan masyarakat.Salah satu contoh: XL Axiatamendukung BPJS dengan yaitu menyediakan layanan pembayaran BPJS Kesehatan melalui XL Tunai. BNI juga membantu meningkatkan kesejahteraan masyarakat dengan pembibitan bambu di Desa Jelengkong, Kecamatan Bale Endah, Bandung.Unilever tetap menjalankan program CSR yang sudah ada yakni, Unilever Sustainable Living Plan (USLP) dalam memelihara kesehatan gigi masyarakat, dan produk-produk bermutu untuk meningkatkan kesehatan masyarakat.KPC memberikan bantuan pengobatan kepada masyarakat tidak mampu melalui Program Operasi Katarak gratis kepada 48 orang berasal dari empat kecamatan. 


\section{National Conference of Creative Industry: \\ Sustainable Tourism Industry for Economic Development}

Universitas Bunda Mulia, Jakarta, 5-6 September 2018

ISSN No: 2622-7436

Aspek dominan yang kedua yaitu, Pendidikan Berkualitas, aspek ini dinyatakan penting karena pendidikan dapat menjadi motor dalam peningkatan taraf hidup di sebuah negara termasuk Indonesia. Terlebih lagi untuk anak-anak yang adalah tunas bangsa dan yang nantinya akan menjadi penerus dan masa depan di negara ini. Dengan demikian, perusahaan berlomba-lomba untuk memberikan kontribusinya dalam aspek pendidikan. XL Axiata menyelenggarakan program "Beasiswa Khazanah", pendidikan ke jenjang pasca sarjana (S2) selama 2 tahun di Malaysia. BNI mengembangkan program kredit pendidikan untuk masyarakat. Unilever mengembangkan program Rumah Pendidikan yang melibatkan 1.920 keluarga karyawan dan masyarakat.KPC mengembangkan Program Celoteh Pendidikan yang bertujuan meningkatkan pengetahuan dan kepedulian masyarakat terhadap berbagai informasi seputar dunia pendidikan melalui radio.Adaro Indonesia memberikan beasiswa bagi anak-anak Dayak. APP memberikan dana beasiswa kepada masyarakat serta pelatihan dalam pertanian maupun peternakan.

Aspek dominan yang ketiga adalah Air Bersih dan Sanitasi, aspek ini menjadi penting terutama di daerah perkotaan.Banyak air bersih yang sudah tercemar dengan polusi dan limbah, sehingga sangat tidak baik bagi kesehatan jika dikonsumsi.Di daerah pelosok pun terkadang masyarakat kesulitan mendapat akses ait bersih, sehingga masyarakat terpaksa mengkonsumsi air kotor yang dapat mengakibatkan banyak penyakit.Dengan demikian, banyak perusahaan yang melakukan suatu tindakan untuk menyediakan air bersih bagi masyarakat maupun edukasi mengenai pentingnya air bersih.Salah satunya adalah XL Axiata bersama lembaga Inisiatif Zakat Indonesia (IZI) meresmikan sistem sarana air bersih (SAB).

BNI melaksanakan Program Kemitraan dan Bina Lingkungan.Berbagai jenis infrastruktur yang telah dibangun adalah salah satunya prasarana air bersih. Unilever BrightFuture bekerjasama dengan Save The Children dengan dukungan dari pemerintahan daerah, meningkatkan akses fasilitas air bersih dan sanitasi. KPC menggunakan air hujan, air dari area pascatambang, dan air daur ulang dari pencucian batubara itu sendiri.Adaro mendistribusikan air bersih dari instalasi pengolahan air Adaro Indonesia kepada masyarakat. Asian Pulp and Paper, sebanyak 258 rumah telah direnovasi, 70 filter pasir bio dipasang untuk menyediakan air bersih dan menghindari keharusan berjalan ke sungai.

Aspek dominan yang keempat adalah Energi Bersih dan Terjangkau.Aspek ini sudah menjadi masalah umum di perkotaan yang memiliki banyak pabrik-pabrik yang menggunakan banyak bahan bakar dalam kegiatan operasionalnya.Perusahaanperusahaan yang tergabung dalam IGCN ternyata memiliki kepedulian dan perhatian mengenai masalah ini.Kegiatan yang dilakukan adalah mencari bahan bakar alternatif.Contoh yang dilakukan XL Axiata dengan berupaya mereduksi pemakaian listrik perusahaan, melalui Smart Electricity yang dilakukan melalui otomatisasi dan sentralisasi pengaturan penerangan dan pendinginan ruangan (AC) pada seluruh gedung Perusahaan.Selain itu, BNI juga melakukan program Earth Hour untuk penghematan listrik. Unilever meningkatkan daya beban pengangkutan hingga 90\%, mengurangi armada dari gudang ke pabrik Cikarang sampai 22\% dan penghematan listrik dengan kampanye kepada karyawan yang bisa menekan pemakaian listrik di gudang sampai 50\%. KPC melakukan Upaya Efisiensi Energi \& Penggunaan Energi Alternatif Ramah Lingkungan. Dalam hal penghematan listrik, Adaro mempertimbangkan penggunaan gas 


\section{National Conference of Creative Industry: \\ Sustainable Tourism Industry for Economic Development}

Universitas Bunda Mulia, Jakarta, 5-6 September 2018

ISSN No: 2622-7436

sebagai energi alternatif karena emisinya relatif lebih rendah dan harganya lebih terjangkau.APP mengurangi batubara intensitas sebesar 3\%.

Aspek dominan yang kelima adalah Konsumsi dan Produksi Bertanggung Jawab.Saat ini banyak pabrik yang juga menggunakan banyak listrik maupun bahan bakar dalam kegiatan operasionalnya.Perusahaan berusaha untuk mengurangi bahan bakar maupun listtik dalam kegiatan operasionalnya. XL mengembangkan program Plastikmu Balikpapan, UKM yang mengolah sampah menjadi produk. BNI mengadakan pelatihan membuat kerajinan tangan dari limbah plastik sehingga dapat berguna untuk meningkatkan pendapatan warga dari sektor ekowisata yang ramah lingkungan. Unilever Meningkatkan pemanfaatan pembuangan limbah panas dari pemanas air di Pabrik Skin \& Deo. KPC memanfaatkan aki bekas, pengumpulan kardus bekas, plastik dan karung bekas dan Limbah B3. APP mendaur ulang lumpur di pabrik mereka dengan menggunakan kembali dalam proses produksi untuk membuat kertas yang lebih rendah dan untuk membuat sol sepatu.

Aspek dominan yang keenam adalah Kemitraan untuk mencapai tujuan.Merupakan suatu strategi yang dilakukan oleh dua pihak atau lebih dalam jangka waktu tertentu untuk meraih keuntungan bersama dengan prinsip saling membutuhkan dan saling mendukung. Perusahaan sadar bahwa mereka tidak dapat bekerja sendiri, dengan demikian banyak perusahaan yang berkolaborasi dengan organisasi lain untuk mencapai tujuan. Seperti XL Axiata yang bekerja sama dengan Yayasan Khazanah menyelenggarakan program "Beasiswa Khazanah" beasiswa pendidikan ke jenjang pasca sarjana (S2) selama 2 tahun di Malaysia. BNI bekerja sama dengan Paguyuban Budiasi kembali mendistribusikan bibit-bibit Tanaman Keras dan Tanaman Langka. BNI juga bekerja sama dengan Komunitas Alaska membagikan 7.000 kantung belanja reusable. Unilever melakukan pengembangan 10.500 petani kedelai hitam dan 25.000 petani gula kelapa untuk memasok bahan baku kecap Bango secara berkelanjutan, melalui kerja sama dengan universitas untuk meningkatkan produktivitas dan pendapatan petani. Adaro bekerja sama dengan Indonesia White Ribbon Alliance (APPI) dengan program Kesehatan Ibu dan Bayi Baru Lahir dan Balita di Desa Dahai dan Desa Warukin.

\section{KESIMPULAN DAN IMPLIKASI}

Berdasarkan hasil penelitian dan pembahasan, maka dapat ditarik simpulan sebagai berikut: (1). Pengungkapan CSR perusahaan apabila ditinjau dari 17 kriteria SDGs tampak masih perlu untuk dikembangkan. Hasil analisis menunjukan terdapat 6 kriteria yang diungkapkan dari 17 kriteria oleh 7 perusahaan yang merupakan subjek penelitian. (2). Tampak dari tabel 1, pengungkapan perusahaan tahun 2015 dan 2016 konsisten artinya informasi yang diungkap 2015, diungkapkan kembali dengan perkembanagn di tahun 2016. Hal ini tampak dari kriteria yang diungkapkan di 2015, oleh perusahaan tersebut diungkapkan kembali di 2016. (3). Pengungkapan yang dominan lebih ke arah sosial daripada lingkungan seperti: kesehatan dan kesejahteraan,pendidikan, air bersih dan sanitasi, konsumen dan kemitraan. Kriteria pada arah lingkungan adalah pemakaian energi.

Hasil penelitian ini menggambarkan pengungkapan dominan oleh perusahaaan yang tergabung di IGCN.Diharapkan penelitian lebih lanjut dapat dilakukan untuk mendeteksi faktor-faktor yang memengaruhi pengungkapan perusahaan dengan studi 
kualitatif dengan metode wawancara ataau kuisioner ataupun studi kuantitatif dengan variabel indipenden seperti ROA atau nilai perusahaan.Bagi perusahaan, hasil penelitian ini dapat dijadikan pemetaan pengungkapan yang dominan dan kurang diungkapkan sehingga dapat meningkatkan motivasi pemgungkapan CSR yang memenuhi kriteria SDGs.

\section{DAFTAR PUSTAKA}

\section{Artikel dalam Jurnal Publikasi}

Budiman, N. T (2015).Faktor-Faktor yang Mempengaruhi Pengungkapan Tanggung Jawab Sosial, 1 (1), 6.

Antule, P., Nangoi, B. N., Suwetja, I G. (2016). Analisis Penerapan Corporate Social Responsibility Terhadap Profitabilitas Pada PT. Bank Tabungan Negara (Persero), Tbk. 4(4), 2.

Aditya Dharmawan Krisna dan Novrys Suhardianto (2016).Faktor-Faktor yang Mempengaruhi Pengungkapan Tanggung Jawab Sosial, Vol. 18, No. 2, 3.

Ang Swat Lin Lindawati dan Marsella Eka Puspita (2015). Corporate Social Responsibility: Implikasi Stakeholder dan Legitimacy Gap dalam Peningkatan Kinerja Perusahaan, 6(1), 7.

I Gst Ngr H. Sawaka K, dan I Gusti A. M. A. D. P. (2016).Analisis Pengungkapan Dan Dampak Penerapan Corporate Social Responsibility di PT Bank Pembangunan Daerah Bali, 16 (2), 842.

Anak A. N. K. P. U., I GAM Asri D. P., (2017). Analisis Pengungkapan Dan Dampak Penerapan Corporate Social Responsibility Di Hotel The Westin Resort Nusa Dua, 19 (1), 30 .

Rickhy George (2013). Implementasi Corporate Social Responsibility di PT. Pembangkit Jawa Bali Unit Pembangkit Gresik.1 (1), 1.

Rifenti Herlinda Wandina, Deasy Arisanty, Ellyn Normelani (2016). Implementasi Program CSR (Corporate Social Responsibility) PT. Adaro Indonesia Bidang Pendidikan di Kecamatan Tanta Kabupaten Tabalong, 3 (6), 3.

Rina Asmeri, Tika Alvionita, and Ardi Gunardi (2017).CSR Disclosures in the Mining Industry: Empirical Evidence from Listed Mining Firms in Indonesia. 1 (1), 2.

Made Aryawan, M., Rahyuda, I. K., Ekawati, N. W. (2017). Pengaruh Faktor Corporate Social Responsibility (Aspek Sosial, Ekonomi, dan Lingkungan ) Terhadap Citra Perusahaan. 6 (2), 2.

Miles, M.B, Huberman,A.M, dan Saldana,J. 2014. Qualitative Data Analysis, A. Methods Sourcebook Edition 3. 


\section{National Conference of Creative Industry: \\ Sustainable Tourism Industry for Economic Development}

Universitas Bunda Mulia, Jakarta, 5-6 September 2018

ISSN No: 2622-7436

\section{Buku}

Sugiyono. (2013). Metode Penelitian Kuantitatif, Kualitatif dan R\&D.Bandung: Alfabeta.CV

Hadi.N. 2014.Corporate Social Responsibility. Graha Ilmu, Yogyakarta.

\section{Sumber Elektronik/Internet}

17 Tujuan Pembangunan Berkelanjutan Diakses: 26 November 2017, dari http://sdgs.bappenas.go.id/

Sejarah Indonesia Global Compact Network. Diakses: 6 Maret 2018 dari http://www.indonesiagcn.org/

Sejarah PT. Unilever Indonesia, Tbk. Dakses: 2 Maret 2018 dari https://www.unilever.co.id/en/about/our-history.html

Sejarah PT. Bank Negara Indonesia, Tbk. Dakses: 2 Maret 2018 darihttp://www.bni.co.id/id-id/perusahaan/tentangbni/sejarah

Laporan berkelanjutan perusahaan PT. Kaltim Prim Coal. Dakses: 2 Maret 2018 dari http://www.kpc.co.id/

Sejarah PT. Pabrik Kertas Tjiwi Kimia, Tbk. Diakses: 2 Maret 2018 dari http://www.tjiwi.co.id/index.php/about-us

Laporan berkelanjutan perusahaan PT. Unilever Ineonesia, Tbk. Diunduh pada 18 Januari 2018 dari https://www.unilever.co.id/investor-relations/publikasiperusahaan/sustainability-report.html

Laporan berkelanjutan perusahaan PT. Kaltim Prima Coal. Diunduh pada 18 Januari 2018 dari http://www.kpc.co.id/kpc-downloads

Laporan berkelanjutan perusahaan PT Bank Negaara Indonesia Tbk. Diunduh pada 18 Januari 2018 dari

http://www.bni.co.id/en-us/company/hubunganinvestor/presentationreport

Laporan berkelanjutan perusahaan PT Adaro Energy Tbk. Diunduh pada 18 Januari 2018 dari

http://www.adaro.com/pages/read/9/51/Sustainability\%20Reports

Laporan berkelanjutan perusahaan PT Pabrik Kertas Tjiwi Kimia dan PT. Indah Kiat Pulp and Paper. Diunduh pada 18 Januari 2018

https://www.asiapulppaper.com/sustainability/policies-reports 